\title{
Microbial Activities and Soil Health in Rice Rhizosphere as Affected by Long Term Integrated Use of Organic and Inorganic Fertilizers
}

\author{
Gaganpreet Kaur Gill $^{1 *}$, S.K. Gosal ${ }^{1}$ and Sandeep Sharma ${ }^{2}$ \\ ${ }^{1}$ Department of Microbiology, Punjab Agricultural University, Ludhiana, 141004, Punjab, India \\ ${ }^{2}$ Soil Sciences, Punjab Agricultural University, Ludhiana, 141004, Punjab, India
}

*Corresponding author

\section{A B S T R A C T}

Keywords

Compost, Enzyme activity, Microbial population, Rice, Sewage sludge

\section{Article Info}

Accepted:

18 April 2016

Available Online: 10 May 2016
Integrated use of organic and inorganic fertilizers can improve crop productivity and sustain soil fertility. Based on this fact, present research was conducted to evaluate the impact of long-term integrated application of sewage sludge, compost and fertilizer nitrogen on microbial activity and soil Health in rice rhizoshere of rice-wheat cropping system. Data revealed that combined application of sewage sludge and inorganic nitrogen significantly increased the population of fungi (46 $\times 103$ cfu g- 1 soil) and actinomycetes $(84 \times 104$ cfu g- 1 soil $)$ whereas compost along with inorganic nitrogen significantly raised bacterial population $(162 \times 108 \mathrm{cfu}$ g1soil), diazotrophic count $(58 \times 105 \mathrm{cfu}$ g-1 soil) and phosphate solubilizer's population $(13 \times 102 \mathrm{cfu}$ g-1soil). Moreover, the integrated application of compost and fertilizer nitrogen recorded significantly higher alkaline phosphatase activity $(221.40 \mu \mathrm{g} \mathrm{pNP} / \mathrm{g}$ of soil/min) and dehydrogenase activity $(8.61 \mu \mathrm{g} \mathrm{TPF} / \mathrm{g}$ of soil/hour) but sewage sludge induced maximum urease activity $(553.60 \mu \mathrm{g} / \mathrm{g}$ of soil/hour) in rice. Maximum decrease in soil $\mathrm{pH}$ was observed by nitrogenous fertilizers alone. Soil microbiological and chemical properties were found to be significantly correlated with each other. Present results demonstrated that integrated application of organic and inorganic sources proved effective alternative source for improving soil health in rice rhizosphere.

\section{Introduction}

Rice is the most important food crop grown in India and rice based cropping system occupies nearly $80 \%$ of agricultural land in South Asia. 'Rice-wheat' grown in annual sequence is the most important cropping system in Indo-Gangatic plains and covers about $11 \mathrm{M}$ ha in India (Jeet et al., 2014).
This cropping system is input intensive and removes more than $600 \mathrm{~kg}$ of NPK nutrients per ha annually when grown under good management conditions (Singh et al., 2003). Despite the past gains in rice production through chemical fertilizers, recent observations of stagnant or declining yields 
have raised concerns about the long-term sustainability of the crop production. The long term use of inorganic fertilizers without organic supplements leads to deterioration in soil physical, chemical and biological properties (Devi et al., 2013).

Emerging evidences suggested that integrated nutrient management (INM) comprising combination of organic and inorganic fertilizers is a promising strategy to sustain agronomic productivity and to improve soil fertility. Nambiar (1997) has reported that integrated use of organic manure and chemical fertilizers is effective not only in providing greater stability but also maintaining better soil fertility status. There is an increasing interest in organic wastes such as sewage sludge and compost as a source of organic matter to soil. Their application not only improves organic matter and essential nutrient contents, but also improves soil structure, aeration, water holding capacity and microbial activities in soil (Webber et al., 1996).

Fertilizer applications to the field have major impact on the activity of microbial population in soil. Soil enzymatic activities serve as a biological indicator of assessing soil quality. Soil enzymes catalyze a wide range of biological processes to release nutrients from organic and inorganic substances. Therefore, these biological attributes are also responsible for determination \& maintenance of physicochemical properties of soil such as soil $\mathrm{pH}$, organic carbon content and amount of available nutrients (nitrogen, phosphorus and potassium) in soil which effect yield of crop.

Long-term experiments are more useful for studying the changes in soil properties over time and for developing future strategies to maintain soil health. Based on these biological and chemical properties of soil, suitable combination of organic and inorganic sources can be determined. Keeping all these points in view, the present study was conducted with an objective to study long term effect of various combinations of organic and inorganic fertilizers on soil microbial population and enzymatic activities in rice rhizosphere of rice-wheat cropping system.

\section{Materials and Methods}

The experiment was conducted in an ongoing field experiment (Since 2009) on rice-wheat cropping system at research farm of Department of Soil Sciences, Punjab Agricultural University, Ludhiana. The experimental field was located at longitude $75^{\circ} 48^{\prime} \mathrm{E}$ and latitude $30^{\circ} 54^{\prime} \mathrm{N}$. The trial was carried out in randomized block design with twelve treatments replications having different combinations of inorganic fertilizers, sewage sludge and compost.

Three nitrogen doses of fertilizer viz. $75 \%$, $100 \% \& 125 \%$ of recommended dose of urea (90 Kg h-1, $120 \mathrm{Kg} \mathrm{h}-1$ and $150 \mathrm{Kg} \mathrm{h}-1$ respectively) in combination of twelve treatments as mentioned in Table 1, were applied to the soil.

All treatments were carried out in triplicate. The plot size was $8 \mathrm{~m} \times 4 \mathrm{~m}$. The source of $\mathrm{N}, \mathrm{P}$ and $\mathrm{K}$ nutrients were urea, single super phosphate and muriate of potash respectively. Phosphorus, potassium and one third of nitrogen were applied at planting and remaining two-third nitrogen was applied after 7-8 weeks of transplanting. The soil samples were collected from $0-15 \mathrm{~cm}$ depth by using auger, after harvest of rice (Oryza Sativa Var. PR 118) in 2014. The collected soil samples were air dried, grounded in a wooden pestle and mortar, passed through a 2-mm plastic sieve and stored for further analysis. 


\section{Enumeration of Microbial Population}

The serial dilution plating technique was employed to enumerate bacteria, fungi, actinomycetes, diazotrophs and phosphorous solubilizers using nutrient Agar medium (Downs ans Ito, 2001), glucose yeast extract medium (Rogosa et al. 1951), kenknight's medium (McBridge and Ensign, 1987), jensen's medium (Jensen, 1942) and NBRIP medium (Nautiyal, 1999), respectively. The count was expressed as CFU g-1 of soil.

\section{Estimation of Soil Enzymatic Activities}

Soil alkaline phosphatase activity was measured by using the method of Tabatabai and Bremner (1969). Extraction of paranitrophenol (pNP) was measured through recording the yellow color intensity at wavelength of $420 \quad \mathrm{~nm}$ using spectrophotometer. Soil urease activity was measured by using the method of Douglas and Bremner (1970). Extracted urea was measured through intensity of red color at $527 \mathrm{~nm}$ wavelength on spectrophotometer.

Soil dehydrogenase activity was measured by using the method of Tabatabai (1982). Extracted triphenyl formazon (TPF) was measured in a spectrophotometer at $480 \mathrm{~nm}$ using methanol as blank.

\section{Soil Texture, pH and Electrical Conductivity}

The soil samples were analyzed for soil texture by hydrometer method, $\mathrm{pH}$ by using Beckman electrode $\mathrm{pH}$ meter and electrical conductivity by solubridge method (Richard, 1954).

\section{Statistical Analysis}

Statistical analysis was performed by Analysis of variance (ANOVA) and Duncan's multiple range test was used to evaluate significant differences between means at $\mathrm{P} \leq 0.05$. Statistical analyses were carried out by using the program CPCS1 and correlation among soil biological and chemical properties was calculated using SPSS software.

\section{Results and Discussion}

\section{Microbial population}

The microbial population viz., bacteria, diazotrophs, fungi, actinomycetes and phosphate solubilizers were affected with the integrated use of organic and inorganic sources as compared to sole application of inorganic fertilizers. Furthermore, similar treatments in rice produced different microbial population reflecting the residual effect of long term use of organic and inorganic sources in rice -wheat cropping system.

Maximum bacterial count $(162 \times 108 \mathrm{cfu} / \mathrm{g}$ soil) was recorded in Treatment 12 (50\% of recommended nitrogen + Compost (10 t/ha) followed by treatment 9 having bacterial population of $148 \times 108 \mathrm{cfu} / \mathrm{g}$ soil and found to be significantly higher from control $(46 \times$ $108 \mathrm{cfu} / \mathrm{g}$ soil). Treatment T12 (50\% of recommended nitrogen + compost @ $10 \mathrm{t} / \mathrm{ha}$ ) was found to be statistically at par with treatment $\mathrm{T} 10 \quad(50 \%$ of recommended nitrogen + compost @10 t/ha), revealing the similarity of these treatments (Table 2).

Similarly, in case of diazotrophs and phosphate solubilizers, maximum count was recorded in treatments having compost followed by Bhattian sludge. Treatment T12 having incorporation of $50 \%$ of recommended nitrogen + Compost (10 t/ha) was observed with highest count of diazotrophs $(58 \times 105 \mathrm{cfu} / \mathrm{g}$ soil $)$ and $\mathrm{p}$ solubilizers $(12.9 \times 102 \mathrm{cfu} / \mathrm{g}$ soil $)$ followed by treatment $\mathrm{T} 11$, showing diazotrophic 
population of $52.8 \times 105 \mathrm{cfu} / \mathrm{g}$ soil and psolubilizers count of $11.5 \times 102 \mathrm{cfu} / \mathrm{g}$ soil (Table 2).

Whereas, in case of fungi and actinomycetes, maximum count was recorded in treatments having Bhattian sludge followed by compost (Table 1). Treatment 8 having $50 \%$ of recommended nitrogen + Bhattian sludge (10t/ha) was observed with highest fungal count $(46 \times$ $103 \mathrm{cfu} / \mathrm{g}$ soil $)$ and actinomycetes $(84 \times 104$ cfu/g soil) followed by treatment 5 (100\% of recommended nitrogen + Bhattian sludge $(5$ t/ha), showing fungal count $(41.8 \times 103$ $\mathrm{cfu} / \mathrm{g}$ soil) and actinomycetes count of $72.1 \times 104 \mathrm{cfu} / \mathrm{g}$ soil.

Treatment T7 (100\% of recommended nitrogen + compost $(5 \mathrm{t} / \mathrm{ha})$ was found to be statistically at par with treatment T5 $(100 \%$ of recommended nitrogen + compost (5 t/ha), due to the effect of similar treatments but was significantly higher from control (11× $103 \mathrm{cfu} / \mathrm{g}$ soil). Moreover, microbial population was found to be positively correlated with organic carbon content and enzyme activity (Table 3 ).

\section{Enzyme activities}

Substitution of $50 \%$ of recommended nitrogen through compost @ 10t/ha (T10) was observed to be more effective in increasing alkaline phosphatase activity (221.40 $\mu \mathrm{g} \quad \mathrm{pNP} / \mathrm{g} \quad$ soil $/ \mathrm{min})$ and dehydrogenase activity (8.61 $\mathrm{g}$ TPF /g soil/hour) followed by substitution through compost@5t/ha (T11) as shown in Figure 1. Whereas, soil urease activity $(553.60 \mu \mathrm{g} / \mathrm{g}$ soil/hour) was found to be maximum in treatment T8 having substitution of $50 \%$ recommended nitrogen through Bhattian sludge (Figure 1).

Treatments having sole application of inorganic sources were recorded with significantly lower enzyme activity as compared to integrated application of organic and inorganic sources. Moreover, enzyme activity was found to be significantly positively correlated with organic matter content as shown in Table 3, indicating that quantity of organic matter in soil has direct influence on enzyme activity.

\section{Soil Texture, pH and Electrical Conductivity}

\section{Soil Texture}

Soil texture is defined as the proportion of sand, silt and clay particles in soil. Texture of soil after rice was observed sandy loam through hydrometer method. The soil texture remained unchanged with long-term treatments including integrated use of inorganic and organic amendments in rice.

\section{Soil pH}

Soil $\mathrm{pH}$ is the soil characteristic, which elucidates an overall picture of the medium for plant growth including fate of added nutrients, salinity/sodicity status, soil aeration and soil mineralogy. Application of compost and sewage sludge in combination with nitrogenous fertilizer reduced the soil $\mathrm{pH}$ significantly as compared to control after rice. Soil $\mathrm{pH}$ was reduced significantly through sole application of nitrogenous fertilizers. Maximum decrease in soil $\mathrm{pH}$ (7.50) was observed through application of $125 \%$ of recommended nitrogen (T4) followed by $100 \%$ of recommended nitrogen (T3) having soil $\mathrm{pH}$ of 7.56. Soil $\mathrm{pH}$ in control (7.82) was found to be decreased slightly in treatments including sewage sludge and compost (Figure 2).

\section{Electrical Conductivity}

Electrical conductivity is a soil parameter 
that indicates indirectly the total concentration of soluble salts and is a direct measurement of salinity. Electrical conductivity showed an increasing trend with the integrated use of inorganic fertilizer with compost and sewage sludge in the soil (Figure 2).

Electrical conductivity in control $(2.28 \mathrm{dS}$ $\mathrm{m}-1)$ was increased to $2.54 \mathrm{dS} \mathrm{m}-1$ in treatment $12 \quad(100 \%$ of recommended nitrogen + compost (10 t ha-1) followed by treatment $9(100 \%$ of $\mathrm{N}(\mathrm{Rec})+$. compost $(5$ t/ha) having electrical conductivity of 2.45 dS m-1. Treatments T3 (100\% of recommended nitrogen) and $\mathrm{T} 9(100 \%$ of recommended nitrogen) were found to be statistically at par with each other.

\section{Microbial population}

Addition of organic inputs (compost and sewage sludge) favored microbial activity and enhanced the soil microbial population by improving soil physical properties. The decreased beneficial effect of sewage sludge may be due to the toxicity of undesirable materials, such as heavy metals, present in sludge. These results are in accordance with Pattanayak et al., 2001, Singh et al., 2001, Selvakumari et al., 2000, Smiciklas et al., 2002 and Sarwar et al., 2003.

The population of fungus and actinomycetes was found higher in sewage sludge amendments as compared to compost. It may be due to the complex organic compounds like lignin, present in sludge favored fungal growth as these compounds are mainly degraded by fungus. These results are in accordance with Niohi (1975) who also reported that complex compounds present in sludge are actively degraded by actinomycetes. Organic matter concentration is also a major factor for growth of actinomycetes. So, higher count was observed in higher doses of organic inputs.

\section{Enzyme activities}

Soil enzymatic activities were observed higher in treatments having higher bacterial population, showing the relationship of microbial biomass with enzyme activity. These results are in accordance with Ndubuisi-Nnaji et al. (2011) who observed the correlation of enzyme activities of soil with organic carbon content and reported that higher levels of organic carbon stimulate microbial activity, and therefore enzyme synthesis.

Sewage sludge was found to be more effective in increasing urease activity. It may be due to the availability of more nitrogenous compounds in sewage sludge as compared to compost. Higher doses of recommended nitrogen negatively affected the urease activity. This fact is supported by Maestre et al. (2011) who reported a decrease in the urease activity with addition of inorganic nitrogen.

\section{Soil pH}

It is evident from the present results that nitrogenous fertilizers affects soil $\mathrm{pH}$ more as compared to organic inputs. Organic inputs have buffering capacity therefore, slight decline in soil $\mathrm{pH}$ occurs. Sharma et al. (2002) also reported a pronounced decline in soil $\mathrm{pH}$ with the application of nitrogenous fertilizers alone. 
Table.1 Treatments

Symbol Treatment details

T1 Control (without N)

$\mathrm{T} 2 \quad 75 \%$ of $\mathrm{N}$ (Recommended)

T3 $100 \%$ of $N$ (Recommended)

T4 $125 \%$ of $N$ (Recommended)

T5 $100 \%$ of $\mathrm{N}($ Rec. $)+$ Bhattian sludge $(5 \mathrm{t} / \mathrm{ha})$

T6 $50 \%$ of $\mathrm{N}($ Rec. $)+$ Bhattian sludge (5 t/ha)

T7 $100 \%$ of $\mathrm{N}($ Rec. $)+$ Bhattian sludge $(5 \mathrm{t} / \mathrm{ha})$

T8 $50 \%$ of $\mathrm{N}($ Rec. $)+$ Bhattian sludge $(10 \mathrm{t} / \mathrm{ha})$

T9 $100 \%$ of $\mathrm{N}($ Rec. $)+\operatorname{compost}(5 \mathrm{t} / \mathrm{ha})$

T10 50\% of $\mathrm{N}($ Rec. $)+$ compost (10 t/ha)

T11 $100 \%$ of $\mathrm{N}($ Rec. $)+$ compost $(5 \mathrm{t} / \mathrm{ha})$

T12 50\% of $\mathrm{N}($ Rec. $)+$ compost $(10 \mathrm{t} / \mathrm{ha})$ 
Table.2 Effect of long term integrated use of organic and inorganic fertilizers on microbial population in rice at harvest

\begin{tabular}{|c|c|c|c|c|c|}
\hline Treatments & $\begin{array}{c}\text { Bacteria } \\
\left(\text { cfu }^{-1} \text { soil } \times 10^{8}\right) \\
\end{array}$ & $\begin{array}{c}\text { Diazotrophs } \\
\left(\text { cfu g }^{-1} \text { soil } \times 10^{5}\right) \\
\end{array}$ & $\begin{array}{c}\text { Fungus } \\
\left(\text { cfu g }^{-1} \text { soil } 10^{3}\right) \\
\end{array}$ & $\begin{array}{l}\text { Actinomycetes } \\
\left(\text { cfu g-1 } \text { g }^{-1} \text { sil } \times 10^{4}\right)\end{array}$ & $\begin{array}{c}\text { PSB } \\
\left(\text { cfu }^{-1} \text { soil } \times 10^{2}\right) \\
\end{array}$ \\
\hline $\mathrm{T} 1$ & 46.0 & 9.0 & 11.0 & 21.0 & 5.4 \\
\hline $\mathrm{T} 2$ & 61.0 & 14.0 & 15.0 & 30.0 & 5.9 \\
\hline $\mathrm{T} 3$ & 78.0 & 29.0 & 18.8 & 35.0 & 6.1 \\
\hline $\mathrm{T} 4$ & 86.8 & 24.0 & 21.0 & 38.5 & 6.8 \\
\hline $\mathrm{T} 5$ & 128.0 & 31.9 & 41.8 & 70.0 & 8.6 \\
\hline $\mathrm{T} 6$ & 105.0 & 35.8 & 39.0 & 68.0 & 8.0 \\
\hline $\mathrm{T} 7$ & 125.0 & 31.0 & 40.8 & 72.1 & 8.6 \\
\hline $\mathrm{T} 8$ & 132.0 & 47.5 & 46.0 & 84.0 & 11.0 \\
\hline T9 & 148.0 & 52.1 & 30.1 & 60.1 & 11.5 \\
\hline $\mathrm{T} 10$ & 160.0 & 58.0 & 34.2 & 66.1 & 12.9 \\
\hline $\mathrm{T} 11$ & 147.8 & 52.8 & 29.1 & 58.9 & 11.5 \\
\hline $\mathrm{T} 12$ & 162.0 & 58.0 & 38.3 & 62.8 & 12.9 \\
\hline $\mathrm{CD}$ at $5 \%$ & 2.69 & 2.76 & 1.84 & 2.07 & 1.18 \\
\hline
\end{tabular}

All values are mean of three replications 
Table.3 Correlation analysis between soil microbial population and enzymatic activities in rice rhizospheric soil

\begin{tabular}{|c|c|c|c|c|c|c|c|c|c|}
\hline & Bac & Fungus & Actino & Diazo & PSB & D & h & $\mathbf{U r}$ & Ap \\
\hline$\overline{\text { Bac }}$ & & - & & - & - & -0 . & $843^{*}$ & $* \quad-$ & - \\
\hline Fungus & & - & & - & - & - & - & - & - \\
\hline Actino & & - & & - & - & - & - & - & - \\
\hline Diazo & & - & & - & - & - & - & - & - \\
\hline PSB & & - & & - & - & - & - & - & $0.955^{* *}$ \\
\hline Deh & & - & & - & - & - & - & - & - \\
\hline $\mathbf{U r}$ & & - & & - & - & - & - & - & - \\
\hline Ap & $0.763^{* *}$ & * & & - & $-0.955^{*}=$ & & - & - & - \\
\hline
\end{tabular}

(Note: Actino $=$ Actinomycetes, Diazo= Diazotrophs, $\mathrm{Bac}=$ Bacteria, $\mathrm{PSB}=$ Phosphate solubilizers, $\mathrm{Ap}=\mathrm{Alkaline}$ phosphatase, $\mathrm{Ur}=\mathrm{Urease}, \mathrm{Dh}=\mathrm{Dehydrogenase}$. $*, * *$ represents significance at $\mathrm{p}=0.05,0.01$ respectively and - represents not significant. 
Fig.1 Effect of long term integrated use of organic and inorganic fertilizers on enzymatic activities in rice at harvest
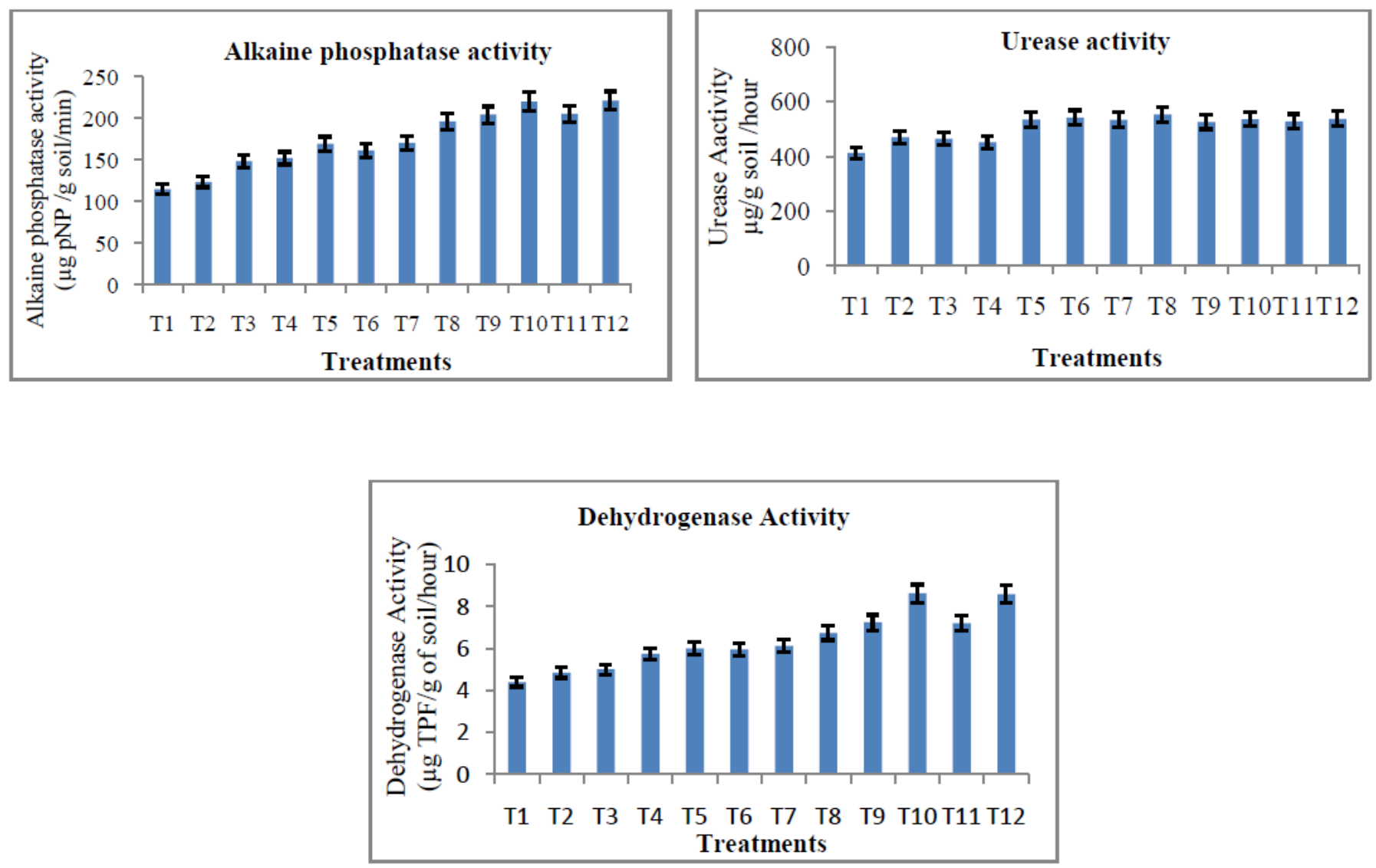
Fig.2 Effect of long term integrated use of organic and inorganic fertilizers on Soil $\mathrm{pH}$ and Electrical Conductivity in rhizospheric soil of rice
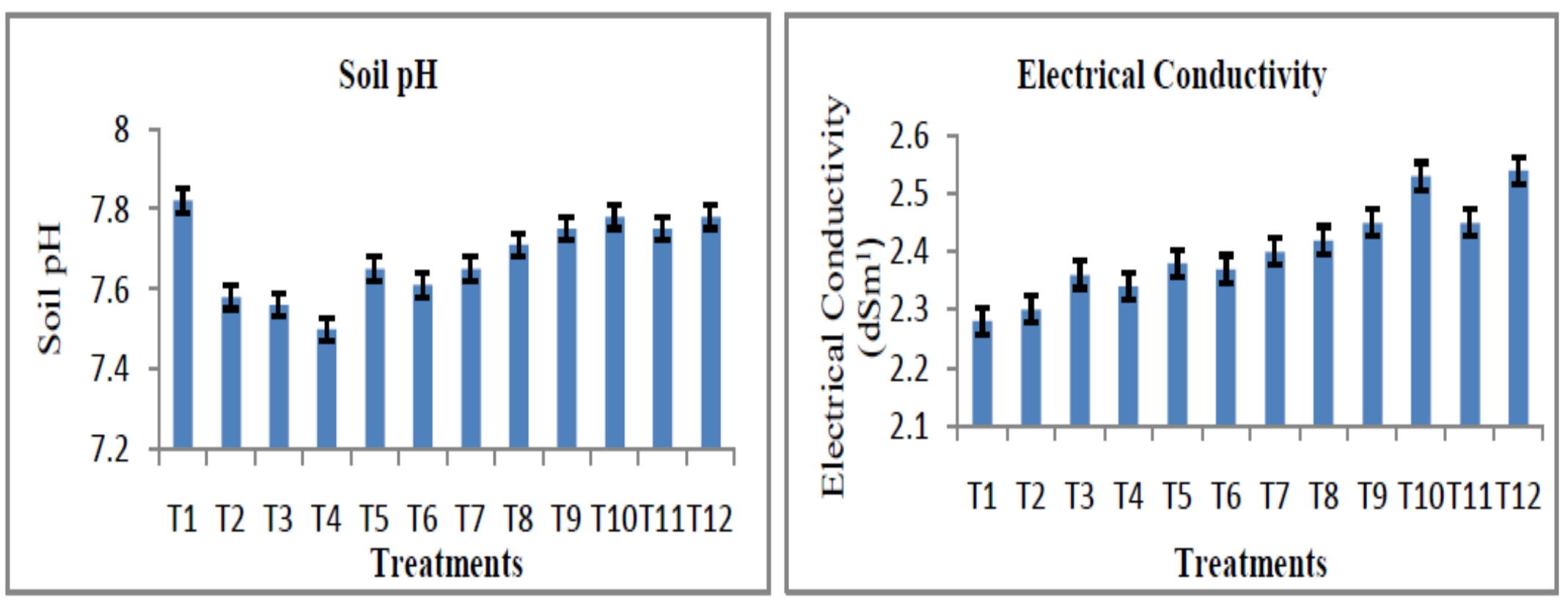
Ghosh et al. (2004) also reported decline in soil $\mathrm{pH}$ with an increase in the levels of NPK from 50 to 150 per cent of optimal dose, as compared to the FYM treated plots over a long period of time.

\section{Electrical Conductivity}

Electrical conductivity was found to be increased by integrated use of organic and inorganic nutrients. It may be due to the production of acids or acid forming compounds through the decomposition of organic materials, that reacted with the sparingly soluble salts already present in the soil or either converted them into soluble salts and increased their solubility. Sarwar et al., 2003, Niklasch \& Joergensen., 2001 and Selvakumari et al., 2000 also reported increase in soil EC due to the application of organic materials to the soil and stated that quantum of increase depend upon the amount of the organic materials applied.

In conclusion, from the above study it can be concluded that integration of inorganic fertilizers with sewage sludge and compost raised the microbial population, enhanced enzymatic activities and effected the soil properties like soil $\mathrm{pH}$ and electrical conductivity in rice rhizospheric soil. The soil $\mathrm{pH}$ and $\mathrm{EC}$ after the harvest of rice was increased with the combined application of inorganic fertilizers with sewage sludge and compost. The overall effect was maximum through compost as compared to sewage sludge. Thus the objective of maintaining soil health can be furnished by a use of inorganic fertilizers along with $50 \%$ substitution through compost.

\section{References}

Devil KN, Singh TB, Athokpam HS, Singh NB, Shamurailatpam D (2013). Influence of inorganic, biological and organic manures on nodulation and yield of soybean
(Glycine max Merril L.) and soil properties. Aus. J. Crop. Sci. 9:1407-1415.

Douglas LA, Bremner JM (1970). Extraction and colorimetric determination of urea in soils. Soil Sci. Soc. Amer. Proc. 34: 859-862.

Downes FP, Ito K (2001). Compendium of Methods for the Microbiological Examination of Foods, 4th Edn, American Public Health Association, Washington.

Ghosh PK, Bandyopadhyay KK, Manna MC, Mandal KG, Misra AK, Hati KM (2004). Comparative effectiveness of cattle manure, poultry manure, phosphocompost and fertilizer NPK on three cropping systems in vertisols of semi-arid tropics. Bioresour. Technol. 95: 85-93.

Hussain N, Hassan G, Arshadullah M, Mujeeb F (2001). Evaluation of amendments for the improvement of physical properties of sodic soil. Intl. J. Agric. Bio. 3:319-322.

Jeet I, Pandey, Singh G, Kumar A (2014). Shankhwar Influence of organic and inorganic sources of nutrients on

growth and yield of rice in Tarai region of Uttarakhand. Ann. Agric. Res. 2: 176-182.

Jensen HL (1942). Nitrogen fixation in leguminous plants. II. Is symbiotic nitrogen fixation influenced by Azotobacter? Proc. Linn. Soc. 57:205-212.

Maestre FT, Puche MD, Guerrero C, Escudero A (2011). Shrub encroachment does not reduce the activity of some soil enzymes in Mediterranean semiarid grasslands. 
Soil Biol. Biochem. 43: 1746-1749.

McBride M, Ensign JC (1987). Effects of intracellular trehalose content on Streptomyces griseus spores. J. Bacteriol. 169:4995-5001

Nambiar, M KK (1997). Soil health and organic matter: Changing scenario. Proc. Nat. Acad. Sci. India. 141160.

Nautiyal CS (1999). An efficient microbiological growth medium for screening phosphate solubilising microorganisms. FEMS Microbiol. Lett. 170: 265-270

Ndubuisi-Nnaji UU, Adegoke AA, Ogbu HI, Ezenobi NO, Okoh AI (2011). Effect of long-term organic fertilizer application on soil microbial dynamics. Afr. J. Biotechnol. 10: 556-559.

Niklasch H , Joergensen RG (2001). Decomposition of peat, biogenic municipal waste compost, and shrub/grass

compost added in different rates to a silt loam. J. Plant Nutr. Soil. Sci. 164: 365-369.

Niohi L (1975). Seasonal variation of microorganisms of in forest soils in relation to vegetation and soil type. J. Soil Manure 46: 369-373.

Pattanayak SK, Mishra NK, Jena MK, Nayak RK (2001). Evaluation of green manure crops fertilized with various phosphorus sources and their effect on subsequent rice crop. J. Indian Soc. Soil. Sci. 49: 285291.

Rasool R, Kakul SS, Hira GS (2007). Soil fertility and crop performance as affected by long term application of

FYM and inorganic fertilizers in rice- wheat cropping system. Soil and Tillage Res. 96:64-72.

Richard LA (1954) Diagnosis and improvement of saline and alkali soils. In (ed): Agriculture HandBook USDA, USA.

Sarwar G, Hussain N, Mujeeb F, Schmeisky H, Hassan H (2003). Biocompost application for the improvement of soil characteristics and dry matter yield of Loliumperenne (Grass). Asian J. Pl. Sci. 2: 237-241.

Selvakumari G, Baskar M, Jayanthi D, Mathan D (2000). Effect of integration of Flyash with fertilizers and organic manures on nutrient availability, yield and nutrient uptake of rice in alfisols. J. Indian Soc. Soil. Sci. 48: 268-278.

Sharma SP, Subehia SK, Sharma AK (2002). Long term effects of chemical fertilizers on soil quality, crop productivity and sustainability. Tech. Bull., Pp 1-33. Palampur.

Singh D D (2003). Management of crop residue in summer rice and its effect on the soil properties and crop yield. Crop Res. 25: 191-193.

Singh S, Singh RN, Prasad J, Kumar B (2002). Effect of green manuring, FYM and biofertilizer in relation to fertilizer nitrogen on yield and major nutrient uptake by upland rice. J. Indian Soc. Soil. Sci. 50: 313-314.

Smiciklas KD, Walker PM, Kelley TR (2002). Utilization of Compost (Food, Paper, Landscape and Manure) in Row Crop Production. Department of Agriculture and Health Sciences, Illinois State 
University, USA.

Tabatabai MA (1982). Soil enzymes In (ed): Methods of soil Analysis, Part 2, Academic Press, New York, pp 903- 947.

Tabatabai MA, Bremner JM (1969). Use of p-nitrophenyl phosphate for assay of soil phosphatase activity. Soil Biol. Biochem. 1:301-07
Webber, Rogers HR, Watts CD, Boxall AB, Davis RD, Scoffin R (1996). Monitoring and prioritisation of organic contaminants in sewage sludge using specific chemical analysis and predictive non analytical methods. Sci. Total Environ. 185: 27-44.

How to cite this article:

Gaganpreet Kaur Gill, S.K. Gosal and Sandeep Sharma. 2016. Microbial Activities and Soil Health in Rice Rhizosphere as Affected by Long Term Integrated Use of Organic and Inorganic Fertilizers. Int.J.Curr.Microbiol.App.Sci.5(5): 568-580.

doi: http://dx.doi.org/10.20546/ijcmas.2016.505.058 